\title{
Atenolol and metoprolol once daily in hypertension
}

\author{
A K SCOTT, J W RIGBY, J WEBSTER, G M HAWKSWORTH, J C PETRIE, H G LOVELL
}

\begin{abstract}
The effect of once-daily dosage of the two most widely prescribed cardioselective beta-adrenoceptor antagonists used to treat hypertension-namely, atenolol and metoprolol-was studied in nine carefully selected hypertensive outpatients. Each patient received atenolol $50 \mathrm{mg}$ / day, atenolol $100 \mathrm{mg} / \mathrm{day}$, metoprolol $100 \mathrm{mg} / \mathrm{day}$, and metoprolol $200 \mathrm{mg} /$ day in a sustained-release formulation (as Lopresor SR) according to a randomised sequence. After three weeks' treatment with each drug given once daily comparisons of the treatments 24 hours after dosing showed no important differences between 50 and $100 \mathrm{mg}$ atenolol/day. Metoprolol, as both the standard and the slow-release formulations, had some limitations in controlling systolic blood pressure and heart rate.

These results suggest that the recommendations for the treatment of hypertension with these cardioselective beta-adrenoceptor antagonists should be reconsidered since doses smaller than those recommended are almost as effective and much cheaper.
\end{abstract}

\section{Introduction}

Once-daily dosage of cardioselective beta-adrenoceptor antagonists in the treatment of hypertension is widely promoted despite uncertainty about the optimal dosage that is effective over 24 hours. For example, atenolol $50 \mathrm{mg}$ once daily has recently been recommended in the United States and Australia, whereas the more costly $100 \mathrm{mg} /$ day is suggested to prescribers in the United Kingdom. Metoprolol $100 \mathrm{mg}$ once daily has been claimed to be effective, ${ }^{12}$ but two manufacturers have developed a slow-release formulation of metoprolol for once-daily use. The aim of this study was to investigate the effects at intervals over 24 hours of different doses of atenolol and metoprolol administered once daily.

\section{Patients and methods}

Nine patients (eight men) with established hypertension and normal renal and hepatic function took part in the study. Their mean age was 37 (range 23-49) years and weight 82 (range 65-102) kg. None of the patients suffered from conditions in which beta-adrenoceptor antagonists were contraindicated. The study was approved by the local area ethical committee, and all patients gave informed written consent to participate in the study.

Each patient received all four treatments in random ordernamely, atenolol $50 \mathrm{mg} /$ day; atenolol $100 \mathrm{mg} /$ day; metoprolol (sustained release; Lopresor SR) $200 \mathrm{mg} /$ day; and metoprolol (Lopresor) $100 \mathrm{mg} /$ day. Any other medication had been withdrawn at least three weeks before the study. Patients attended the ward for

Department of Therapeutics and Clinical Pharmacology, University of Aberdeen, Aberdeen AB9 2ZD

A K SCOTT, MB, MRCP, lecturer

J W RIGBY, BSC, research fellow

J WEBSTER, MD, MRCP, lecturer

G M HAWKSWORTH, PHD, senior lecturer

J C PETRIE, MB, FRCP, reader

Department of Statistics, University of Aberdeen

H G LOVELL, BA, senior lecturer training and familiarisation with the techniques and procedures and for untreated values to be recorded. On the last day of each threeweek period of active treatment the patients attended the ward between 8 and 9 am, 24 hours after their last dose. Heart rate and blood pressure were measured. A further dose was then given and the measurements repeated four and 12 hours after this final dose in each treatment period. Heart rates and blood pressures were recorded sitting (in duplicate) after 10 minutes' rest, standing (in duplicate) after two minutes, during exercise after three minutes on a treadmil at $15 \%$ (at a speed predetermined for each patient to achieve untreated exercise heart rate of $>140$ beats $/ \mathrm{min}$ ), and 30 seconds after exercise. The observer was unaware of the treatment being given. A Remler recorder (M2000) coupled direct to a decoder (M3000) was used for simultaneous measurement of both heart rate and blood pressure. On the day of each study the patients had a light breakfast, went about their usual daily routine (other than ward visits for recording), and were forbidden alcohol, cigarettes, and caffeine-containing drinks.

Blood samples $(10 \mathrm{ml})$ were taken within two minutes of each postexercise recording and analysed by gas-liquid chromatography with electron capture detection (atenolol ${ }^{4}$; metoprolol ${ }^{5}$ ).

Data on heart rate and systolic and diastolic pressures in the different positions were analysed by analyses of variance. Because of interactions separate analyses of variance were then computed for elapsed times of four, 12, and 24 hours. Pairs of means were compared by Scheffé's method, which adjusts significance levels to allow for multiple comparisons, and the results confirmed using Wilcoxon's signed rank test, which requires less stringent assumptions regarding the type of measurements being made.

\section{Results}

Heart rates and blood pressure-Table I shows the mean sitting, standing, exercise, and postexercise heart rates and systolic and diastolic blood pressures at four, 12, and 24 hours after dosing for the four treatments. Values for the least significant differences at the $5^{\circ}$ level are included and indicate the smallest difference between any pair of means that would be declared significant at the $5 \%$ level. Each value is appropriate for any of the six pairs of differences that can be selected from the four means. The use of least significant differences rather than standard errors of means allows for direct interpretation of clinically relevant differences between treatments.

Heart rate and systolic blood pressure-Four and 12 hours after dosing the mean values of these two variables were similar in each position for all treatments. At 24 hours after dosing the effects of both doses of atenolol were similar. Comparisons of the four treatments favoured atenolol (table II).

Diastolic blood pressure-No significant differences were evident between the treatments in diastolic blood pressure in any position at any of the times measured.

Blood concentrations-Table III shows blood concentrations of the drugs four, 12, and 24 hours after dosing for the four treatments. In each case the concentrations were correlated with the dose administered.

\section{Discussion}

This study shows that the present recommendations for dosages of both atenolol and metoprolol in the management of hypertension should be reconsidered. There seems little to justify the routine initial prescription of atenolol $100 \mathrm{mg} /$ day when the lower dose is almost as effective and much cheaper (by $£ 24 /$ patient/year). A previous study by our group showed that 50,100 , and $200 \mathrm{mg}$ atenolol once daily had similar effects, but the study did not include measurements at four and 12 hours after dosing or during exercise, or measurements of blood concentrations. ${ }^{6}$ Thus for reasons of cost and effectiveness 
TABLE I-Mean heart rate and blood pressure and $5 \%$ least significant difference (LSD) at four, 12 , and 24 hours after 21 days' treatment with atenolol 50 mg/day, atenolol $100 \mathrm{mg} /$ day, sustained-release metoprolol $200 \mathrm{mg} /$ day, and metoprolol $100 \mathrm{mg} /$ day $(n=9)$

\begin{tabular}{|c|c|c|c|c|c|c|c|c|c|c|c|c|c|c|c|c|c|}
\hline & & \multirow{2}{*}{\multicolumn{6}{|c|}{ Heart rate (beats/min) }} & \multicolumn{10}{|c|}{ Blood pressure $(\mathrm{mm} \mathrm{Hg})$} \\
\hline & & & & & & & & \multicolumn{5}{|c|}{ Systolic } & \multicolumn{5}{|c|}{ Diastolic } \\
\hline & & \multicolumn{3}{|c|}{ Atenolol } & \multicolumn{2}{|c|}{ Metoprolol } & \multirow{2}{*}{ LSD } & \multicolumn{2}{|c|}{ Atenolol } & \multicolumn{2}{|c|}{ Metoprolol } & \multirow{2}{*}{ LSD } & \multicolumn{2}{|c|}{ Atenolol } & \multicolumn{2}{|c|}{ Metoprolol } & \multirow{2}{*}{ LSD } \\
\hline & & & $50 \mathrm{mg}$ & $100 \mathrm{mg}$ & $200 \mathrm{mg}$ & $100 \mathrm{mg}$ & & $50 \mathrm{mg}$ & $100 \mathrm{mg}$ & $200 \mathrm{mg}$ & $100 \mathrm{mg}$ & & $50 \mathrm{mg}$ & $100 \mathrm{mg}$ & $200 \mathrm{mg}$ & $100 \mathrm{mg}$ & \\
\hline & & & \multicolumn{15}{|c|}{ At four hours } \\
\hline $\begin{array}{l}\text { Sitting } \ldots \\
\text { Standing } \ldots \\
\text { During exercise } \\
\text { After exercise }\end{array}$ & $\begin{array}{l}\ldots \\
\cdots \\
\cdots\end{array}$ & $\begin{array}{l}\because \\
\because \\
\because\end{array}$ & $\begin{array}{r}74 \\
81 \\
116 \\
93\end{array}$ & $\begin{array}{r}74 \\
79 \\
113 \\
87\end{array}$ & $\begin{array}{r}71 \\
78 \\
118 \\
88\end{array}$ & $\begin{array}{r}78 \\
84 \\
117 \\
96\end{array}$ & $\begin{array}{r}8 \\
9 \\
9 \\
13\end{array}$ & $\begin{array}{l}120 \\
124 \\
153 \\
145\end{array}$ & $\begin{array}{l}115 \\
118 \\
149 \\
141\end{array}$ & $\begin{array}{l}119 \\
124 \\
156 \\
148\end{array}$ & $\begin{array}{l}123 \\
130 \\
153 \\
150\end{array}$ & $\begin{array}{r}9 \\
9 \\
16 \\
12\end{array}$ & $\begin{array}{l}85 \\
89 \\
83 \\
84\end{array}$ & $\begin{array}{l}87 \\
89 \\
80 \\
85\end{array}$ & $\begin{array}{l}84 \\
93 \\
84 \\
89\end{array}$ & $\begin{array}{l}89 \\
93 \\
85 \\
93\end{array}$ & $\begin{array}{r}7 \\
9 \\
13 \\
10\end{array}$ \\
\hline & & & & \multicolumn{14}{|c|}{ At 12 hours } \\
\hline $\begin{array}{l}\text { Sitting } \quad . . \\
\text { Standing . } \\
\text { During exercise } \\
\text { After exercise }\end{array}$ & $\begin{array}{l}\cdots \\
\cdots \\
\cdots\end{array}$ & $\begin{array}{l}\ldots \\
\cdots \\
\cdots\end{array}$ & $\begin{array}{r}79 \\
88 \\
125 \\
100\end{array}$ & $\begin{array}{r}76 \\
81 \\
119 \\
92\end{array}$ & $\begin{array}{r}75 \\
81 \\
122 \\
95\end{array}$ & $\begin{array}{r}83 \\
92 \\
132 \\
109\end{array}$ & $\begin{array}{l}11 \\
11 \\
13 \\
17\end{array}$ & $\begin{array}{l}124 \\
129 \\
166 \\
160\end{array}$ & $\begin{array}{l}124 \\
124 \\
156 \\
151\end{array}$ & $\begin{array}{l}131 \\
135 \\
167 \\
160\end{array}$ & $\begin{array}{l}127 \\
136 \\
171 \\
162\end{array}$ & $\begin{array}{l}12 \\
11 \\
15 \\
13\end{array}$ & $\begin{array}{l}85 \\
91 \\
81 \\
86\end{array}$ & $\begin{array}{l}83 \\
88 \\
81 \\
86\end{array}$ & $\begin{array}{l}86 \\
93 \\
85 \\
90\end{array}$ & $\begin{array}{l}86 \\
94 \\
81 \\
86\end{array}$ & $\begin{array}{r}8 \\
9 \\
14 \\
11\end{array}$ \\
\hline & & & \multicolumn{15}{|c|}{ At 24 hours } \\
\hline $\begin{array}{l}\text { Sitting ... } \\
\text { Standing . } \\
\text { During exercise } \\
\text { After exercise }\end{array}$ & $\begin{array}{l}\ldots \\
\cdots \\
\cdots\end{array}$ & $\begin{array}{l}. \\
\cdots \\
\cdots\end{array}$ & $\begin{array}{r}87 \\
97 \\
127 \\
112\end{array}$ & $\begin{array}{r}81 \\
88 \\
124 \\
101\end{array}$ & $\begin{array}{r}87 \\
98 \\
143 \\
120\end{array}$ & $\begin{array}{l}100 \\
108 \\
156 \\
136\end{array}$ & $\begin{array}{l}12 \\
11 \\
17 \\
20\end{array}$ & $\begin{array}{l}124 \\
125 \\
173 \\
160\end{array}$ & $\begin{array}{l}120 \\
122 \\
166 \\
149\end{array}$ & $\begin{array}{l}133 \\
136 \\
182 \\
165\end{array}$ & $\begin{array}{l}130 \\
138 \\
187 \\
163\end{array}$ & $\begin{array}{r}11 \\
9 \\
15 \\
18\end{array}$ & $\begin{array}{l}87 \\
92 \\
84 \\
89\end{array}$ & $\begin{array}{l}83 \\
88 \\
84 \\
88\end{array}$ & $\begin{array}{l}88 \\
93 \\
84 \\
88\end{array}$ & $\begin{array}{l}87 \\
95 \\
82 \\
89\end{array}$ & $\begin{array}{r}7 \\
7 \\
15 \\
13\end{array}$ \\
\hline
\end{tabular}

TABLE II-Significances of differences between drugs in heart rate and systolic blood pressure in each position 24 hours after dosing (assessed using Scheffe's method)

\begin{tabular}{|c|c|c|c|c|c|c|c|}
\hline & & $\begin{array}{l}\text { Atenolol } 100 \mathrm{mg} \\
v v \\
\text { atenolol } 50 \mathrm{mg}\end{array}$ & $\begin{array}{c}\text { Atenolol } 100 \mathrm{mg} \\
v \\
\text { sustained-release } \\
\text { metoprolol } 200 \mathrm{mg}\end{array}$ & $\begin{array}{l}\text { Atenolol } 100 \mathrm{mg} \\
v \\
\text { metoprolol } 100 \mathrm{mg}\end{array}$ & $\begin{array}{c}\text { Atenolol } 50 \mathrm{mg} \\
v \\
\text { sustained-release } \\
\text { metoprolol } 200 \mathrm{mg}\end{array}$ & $\begin{array}{c}\text { Atenolol } 50 \mathrm{mg} \\
\text { metoprolol } 100 \mathrm{mg}\end{array}$ & $\begin{array}{l}\text { Sustained-release } \\
\text { metoprolol } 200 \mathrm{mg} \\
v \\
\text { metoprolol } 100 \mathrm{mg}\end{array}$ \\
\hline $\begin{array}{l}\text { Sitting: } \\
\quad \text { Heart rate } \quad \ldots \quad \ldots \\
\text { Systolic blood pressure }\end{array}$ & $\because$ & $\begin{array}{l}\text { NS } \\
\text { NS }\end{array}$ & $\begin{array}{l}\text { NS } \\
<0.05\end{array}$ & $\begin{array}{l}<0.01 \\
\text { NS }\end{array}$ & $\begin{array}{l}\text { NS } \\
\text { NS }\end{array}$ & $\begin{array}{l}<0.05 \\
\text { NS }\end{array}$ & $\begin{array}{l}<0.05 \\
\text { NS }\end{array}$ \\
\hline $\begin{array}{l}\text { Heart rate } \\
\text { Systolic blood pressure } \\
\text { During exercise: }\end{array}$ & $\because$. & $\begin{array}{l}\text { NS } \\
\text { NS }\end{array}$ & $\underset{<0 \cdot 01}{N S}$ & $\begin{array}{l}<0.01 \\
<0.01\end{array}$ & $\begin{array}{l}\text { NS } \\
<0.05\end{array}$ & $\begin{array}{l}<0.05 \\
<0.01\end{array}$ & $\begin{array}{l}\text { NS } \\
\text { NS }\end{array}$ \\
\hline $\begin{array}{l}\text { Heart rate } \\
\text { Systolic blood pressure } \\
\text { After exercise: }\end{array}$ & $\because$ & $\begin{array}{l}\text { NS } \\
\text { NS }\end{array}$ & $\begin{array}{l}<0.05 \\
<0.05\end{array}$ & $\begin{array}{l}<0.01 \\
<0.01\end{array}$ & $\begin{array}{l}\text { NS } \\
\text { NS }\end{array}$ & $\begin{array}{l}<0.01 \\
\text { NS }\end{array}$ & $\begin{array}{l}\text { NS } \\
\text { NS }\end{array}$ \\
\hline $\begin{array}{l}\text { Heart rate } \\
\text { Systolic blood pressure }\end{array}$ & $\begin{array}{l}. . \\
-\end{array}$ & $\begin{array}{l}\text { NS } \\
\text { NS }\end{array}$ & $\begin{array}{l}\text { NS } \\
\text { NS }\end{array}$ & $\begin{array}{l}<0.01 \\
\text { NS }\end{array}$ & $\begin{array}{l}\text { NS } \\
\text { NS }\end{array}$ & $\begin{array}{l}<0.05 \\
\text { NS }\end{array}$ & $\begin{array}{l}\text { NS } \\
\text { NS }\end{array}$ \\
\hline
\end{tabular}

TABLE III-Mean + SEM blood drug concentrations $(\mu g / l)$ four, 12 , and 24 hours after dosing

\begin{tabular}{|c|c|c|c|c|}
\hline \multirow{2}{*}{$\begin{array}{l}\text { Time } \\
\text { after } \\
\text { dosing }\end{array}$} & \multicolumn{2}{|c|}{ Atenolol } & \multicolumn{2}{|c|}{ Metoprolol } \\
\hline & $50 \mathrm{mg}$ & $100 \mathrm{mg}$ & $\begin{array}{c}200 \mathrm{mg} \\
\begin{array}{c}\text { (sustained } \\
\text { release) }\end{array}\end{array}$ & $100 \mathrm{mg}$ \\
\hline $\begin{array}{l}4 \text { hours } \\
12 \text { hours } \\
24 \text { hours }\end{array}$ & $\begin{array}{rr:r} & 330 & 56 \\
\ldots & 125 & 19 \\
\ldots & 51 & 8\end{array}$ & $\begin{array}{r}668: 42 \\
261: 36 \\
96 \div 8\end{array}$ & $\begin{array}{r:r}212 & 55 \\
74 & 24 \\
34 & 16\end{array}$ & $\begin{array}{r:r}111 & 28 \\
19 & 6 \\
15 & 4\end{array}$ \\
\hline
\end{tabular}

we now prescribe $50 \mathrm{mg}$ once daily as initial treatment. Further studies are required to establish whether the resultant lower peak and steady-state blood concentrations will be associated with a reduction in insidious side effects, such as fatigue, especially during severe exercise.

In this study the treatments were compared using analysis of variance rather than multiple comparisons based on simple $t$ tests. The use of $t$ tests would produce too many apparently significant differences between treatments. Using least significant differences breaks with the tradition of showing mean values \pm standard errors of the means. The smallest difference between any pair of means that would be declared significant at the 5\% level is a more useful statistic because no further calculations are required to appreciate the significance of the difference between a pair of means. Quantification of such least significant differences permits some clinical weighting to be applied to observed differences between treatments. For example, at 24 hours after dosing, during exercise, differences between treatments of more than 17 beats/minute or $15 \mathrm{~mm} \mathrm{Hg}$ systolic blood pressure will show up as significant at the $5 \%$ level. In our view differences of less than these values during exercise are not likely to be clinically important. For sitting and standing smaller differences between treatments will show up as significant at the 5\% level (table I). For diastolic blood pressure differences between treatments of less than $7 \mathrm{~mm} \mathrm{Hg}$ would not show up as significant at the $5 \%$ level, but such minor differences are unlikely to be of clinical importance.

We previously compared atenolol and metoprolol given twice daily (200 mg and $400 \mathrm{mg}$ daily) and found no important differences.? Our present study shows that 24 hours after dosing comparisons of lower doses of atenolol and metoprolol given once daily, even using a slow-release formulation of metoprolol, do not favour metoprolol. The $100 \mathrm{mg}$ standard formulation of metoprolol has limitations for once-daily dosage, while the higher dose of the slow-release formulation also has limitations compared with both doses of atenolol in controlling heart rates and systolic blood pressure.

Two principal claims are made by proponents of once-daily treatment with beta-adrenoceptor antagonists, and each merits critical consideration. The more important is that control of heart rate and blood pressure 24 hours after dosing is necessary to reduce morbid events and mortality. There is little accumulated evidence to support such claims. Blood pressure is lower during sleep, and the achievement of blood concentrations of drugs necessary to inhibit exercise-induced tachycardia is seldom appropriate in the early hours of the morning if this time coincides with the terminal phase of the dosing interval. Nevertheless, if claims are made for the effectiveness of a formulation of a drug 24 hours after dosing then such claims should withstand scrutiny. As we have shown in this study and previously ${ }^{*}$. this is not always the case. The less important claim is that once-daily dosing improves compliance of the patient with drug treatment. We do not consider that this is proved. 
We thank Geigy Pharmaceuticals and ICI Limited for financial support.

\section{References}

1 Comerford MB, Besterman EM. Relative activity of atenolol and metoprolol. Br Med f 1977;ii :260.

${ }^{2}$ Rasmussen S, Arnung K, Eskildsen PC, Nielsen PE. A comparative study of atenolol and metoprolol in the treatment of hypertension. Br f Clin Pharmacol 1981;12:887-91.

3 Scott AK, Petrie JC. Assessment of Remler blood pressure recording system. Br f Clin Pharmacol 1982;13:289-90.
4 Scales B, Copsey PB. The gas chromatographic determination of atenolol in biological samples. $\mathcal{f}$ Pharm Pharmacol 1975;27:430-3.

5 Degen PH, Reiss W. Simplified method for the determination of oxprenolol and other $\beta$-receptor blocking agents in biological fluids by gas-liquid chromatography. 7 Chromatogr 1976;121:72-5.

- Jeffers TA, Webster J, Petrie JC, Barker NP. Atenolol once-daily in hypertension. Br f Clin Pharmacol 1977;4:523-7.

7 Jeffers TA, Webster J, Reid BR, Petrie JC. Atenolol and metoprolol in mild hypertension. $\mathrm{Br}$ Med f 1978; ii :1269-70.

${ }^{8}$ Petrie JC, Jeffers TA, Robb OJ, Scott AK, Webster J. Atenolol, sustainedrelease oxprenolol, and long-acting propranolol in hypertension. Br Med F 1980;280:1573-5.

(Accepted 11 February 1982)

\title{
Blood carboxyhaemoglobin, plasma thiocyanate, and cigarette consumption: implications for epidemiological studies in smokers
}

\author{
C J VESEY, Y SALOOJEE, P V COLE, M A H RUSSELL
}

\begin{abstract}
Carboxyhaemoglobin and plasma thiocyanate concentrations were found to be significantly correlated with self-reported daily cigarette consumption in 360 smokers $(r=0.416$ and 0.412 respectively; $p<0.001)$. The extent to which inhalation patterns affected the intake of cigarette smoke constituents was determined from the partial correlation between carboxyhaemoglobin and plasma thiocyanate concentrations after the number of cigarettes smoked per day had been allowed for $(r=0 \cdot 48)$. Thus $23 \%$ of the variation in carboxyhaemoglobin and thiocyanate concentrations was accounted for by the way a cigarette was smoked and a further $21 \%$ by the number smoked a day. Furthermore, the relation between carboxyhaemoglobin or plasma thiocyanate and daily cigarette consumption was not linear but reached an asymptote at consumption rates above 25 cigarettes a day.

These results suggest that by itself daily cigarette consumption will not identify those smokers most at risk and will also underestimate the dose-response relationship between smoking and selected diseases.
\end{abstract}

\section{Introduction}

It is generally accepted that the health risks associated with smoking increase in proportion to the number of cigarettes smoked a day. This presupposes that daily cigarette consumption is an adequate index of exposure to the toxic agents in tobacco smoke. Consumption may, however, be a poor measure of dose since smokers can vary their intake of smoke in other ways-by regulating the length and depth of inhalation or by the number

\footnotetext{
Anaesthetics Laboratory, St Bartholomew's Hospital, London EC1A 7BE

C J VESEY, MSC, MIBIOL, research assistant

Y SALOOJEE, MIBIOL, research assistant

P V COLE, FFARCS, consultant anaesthetist

Addiction Research Unit, Institute of Psychiatry, London E5

M A H RUSSELL, MRCP, FRCPSYCH, senior lecturer
}

and size of puffs. ${ }^{1}$ Will a true estimate of the hazards of smoking then be provided by epidemiological studies which use daily cigarette consumption to determine exposure, or does a more accurate assessment need objective measures of tobacco smoke intake?

We have measured blood carboxyhaemoglobin and plasma thiocyanate concentrations in cigarette smokers in the course of other smoking-related studies. This has provided us with data to examine the relation between dose and cigarette consumption.

\section{Subjects and methods}

The subjects studied were all healthy volunteers and were either non-smoking or smoking members of staff at St Bartholomew's Hospital or smokers attending the Maudsley Hospital. There were 360 smokers ( 178 men and 182 women) and 79 non-smokers ( 51 men and 28 women). Venous blood was taken from each subject, usually in the late morning or afternoon, for the estimation of carboxyhaemoglobin and plasma thiocyanate. Carboxyhaemoglobin concentrations were determined with an IL282 CO-Oximeter ${ }^{2}$ and plasma thiocyanate by an automated modification of the Aldridge technique. ${ }^{3}$ These procedures have been described more fully elsewhere. ${ }^{4}$

\section{Results}

The smokers were subdivided into six classes on the basis of their daily cigarette consumption. The class intervals chosen allowed for digit bias in reporting daily consumption; $49^{\circ}$ ' of our subjects recorded numbers as 10 or multiples thereof. Details of the number of subjects, average cigarette consumption, and mean (SEM) carboxyhaemoglobin or plasma thiocyanate concentrations in each smoking class and in non-smokers are shown in fig 1 . The significance of the differences in mean carboxyhaemoglobin or plasma thiocyanate concentrations between adjacent classes, using the Mann-Whitney $U$ test, is also given. The biochemical measures each showed an asymptotic relationship with daily cigarette consumption. Initially the concentrations of these compounds rose rapidly and then reached a plateau at consumption rates above 25 cigarettes a day. The increases in the mean concentrations of carboxyhaemoglobin were relatively greater than those for plasma thiocyanate, shown by the appropriate selection of scales in fig 1 .

The ranges of carboxyhaemoglobin and plasma thiocyanate concentrations within the six smoking classes are shown in fig 2 . The separation between the cumulative distribution curves was distinct 